\title{
RELATIVIZAÇÃO DA COISA JULGADA MATERIAL NO PROCESSO CIVIL BRASILEIRO*
}

\section{RELATIVIZATION OF THE MATERIAL “RES JUDICATA” IN THE BRAZILIAN CIVIL SUIT}

\author{
Maria Isabel Araujo
}

\begin{abstract}
Resumo: Trata da polêmica sobre a relativização da coisa julgada no processo civil de tutela cognitiva individual, quando a sentença afronta normas ou princípios constitucionais. Enfoca que somente as sentenças existentes, que produzem coisa julgada inconstitucional ou injusta, podem ser relativizadas. Aponta o princípio da proporcionalidade como método ou critério adequado para resolver o conflito de valores. Somente a ponderação de valores, no caso concreto, é capaz de determinar se a coisa julgada deve ser mantida ou não na ordem jurídica. Para relativizar a coisa julgada inconstitucional propõe o cabimento de uma ação desconstitutiva, com as mesmas características da ação rescisória, mas não sujeita a prazo.
\end{abstract}

Palavras-chave: Coisa Julgada. Princípio da Proporcionalidade. Relativização.

\begin{abstract}
It also addresses the debate about the revitalization of the res judicata in the civil suit of the individual cognitive tutelage when the sentence goes against constitutional norms or principles. It highlights that only the existent sentences, which lead to res judicata unconstitutional or unjust, may be relativized. It sees the principle of proportionality as a method or criterion adequate to solve the conflict of values that arises when the law enforcer is faced with an unfair or unconstitutional sentence. Only the consideration upon values, in a true case, is able to determine whether the res judicata must be kept or not in the juridical order. To relativize the res judicata unconstitutional a de-constitutive action is proposed, with the same characteristics of a rescinding action, but not subject to terms of duration.
\end{abstract}

Keywords: Res Judicata. Principle of Proportionality. Relativization.

Este artigo é resultado da dissertação defendida no mestrado em Direito Negocial em 2006 na Universidade Estadual de Londrina (UEL).

"Mestre em Direito Negocial pela UEL. 


\section{INTRODUÇÃO}

A relativização, flexibilização, mitigação ou desconstituição da coisa julgada são temas que vêm sendo estudados por vários doutrinadores modernos.

Mas o interesse pelo assunto cresce à medida que são apresentados casos práticos, com sentenças que transitam materialmente em julgado, mas são injustas ou inconstitucionais. Nesses casos, essas sentenças devem prevalecer no ordenamento jurídico mesmo depois de ultrapassado o prazo da ação rescisória?

O estudo desenvolvido procura apresentar uma resposta a esta indagação, a partir de uma perspectiva que não pretende ser a única, mas se revela possível e coerente ao sistema processual civil brasileiro.

A chamada 'relativização' da coisa julgada material será estudada à luz do princípio da proporcionalidade, este entendido como método eficaz de resolução de conflito de princípios.

Portanto, o trabalho pretende ponderar, no caso concreto, o valor 'segurança' e o valor 'justiça', considerando que o dogma da coisa julgada garante a segurança jurídica e a relativização visa buscar a justiça das decisões.

A partir das recentes propostas de relativização formuladas pela doutrina brasileira, procura-se perquirir o meio mais adequado para "relativizar" a coisa julgada material inconstitucional ou injusta, quando já houver ultrapassado o biênio legal para a propositura da ação rescisória.

\section{COISA JULGADA}

A origem da coisa julgada confunde-se, ainda que parcialmente, com a origem do processo, desde os romanos até os tempos modernos.

A idéia de "coisa julgada" surge da noção de processo como "contrato", pois foi afirmado por Pothier (apud COUTURE, 1946, p. 91) que:

o efeito da coisa julgada entre as partes nada mais era que a conseqüência lógica do princípio de que as convenções somente afetam os contratantes, e que a origem da coisa julgada é a convenção, ou seja, o acordo entre as partes chamado "contrato judicial”, pelo qual ambos os litigantes se põem de acordo em submeter à decisão do juiz o litígio que os divide.

A coisa julgada, assim como o processo, surge para trazer segurança aos homens, que precisam ter um mínimo de certeza sobre as relações sociais decididas pelo direito.

A definição doutrinária mais conhecida de coisa julgada é a de Enrico Túlio Liebman (1984, p. 54), segundo o qual a coisa julgada é "a imutabilidade do 
comando emergente de uma sentença, que atinge além do conteúdo, também os efeitos da sentença".

Contudo, o conceito de coisa julgada é polêmico. No Brasil, a definição de Liebman foi criticada por Barbosa Moreira (1984, p. 110), para quem a coisa julgada "é uma situação jurídica em que ingressa a sentença, ao atingir uma estabilidade peculiar”. Ou seja, a coisa julgada é a imutabilidade do comando emergente da sentença, atingindo apenas o conteúdo e não os seus efeitos.

A coisa julgada é um instituto importante para o ordenamento jurídico brasileiro, tanto que está prevista no Art. 5aㅡ, XXXVI, da Constituição Federal; no Art. 6 $6^{a}$, § 3 $3^{\underline{a}}$, da Lei de Introdução ao Código Civil; nos Arts. 467 a 475, do Código de Processo Civil e, ainda, em várias leis esparsas. De forma implícita, a coisa julgada está protegida como um corolário do princípio da segurança jurídica,

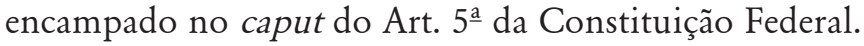

Liebman (1984, p. 60) considera a coisa julgada sob dois aspectos, o formal e o material, pois ela "consiste na imutabilidade da sentença na sua existência formal e, ainda, na imutabilidade dos efeitos dessa sentença”.

Enquanto todas as sentenças são suscetíveis de coisa julgada formal, apenas as sentenças de mérito formam a coisa julgada material. Eduardo Talamini (2005, p. 30) defende que "a coisa julgada material é uma qualidade de que se reveste a sentença de cognição exauriente de mérito transitada em julgado, qualidade essa consistente na imutabilidade do conteúdo do comando sentencial”.

Portanto, a doutrina mais recente já consagrou a idéia de que a coisa julgada não atinge os efeitos da decisão de mérito transitada em julgado, mas sim o conteúdo do comando da sentença, como sempre destacou Barbosa Moreira.

A coisa julgada formal é a imutabilidade da decisão final dentro do processo, enquanto a coisa julgada material é a imutabilidade do conteúdo do comando da decisão final de mérito (sentença ou acórdão) para além do processo.

Assim, o instituto da coisa julgada representa a consolidação do princípio da segurança jurídica, pois, uma vez transitada em julgado a sentença, não se pode mais discutir essa decisão, ressalvados os casos dos instrumentos processuais que podem desconstituíla (como é o caso da ação rescisória).

As propostas de relativização da coisa julgada procuram, por sua vez, alcançar a "justiça" do caso concreto. $\mathrm{Na}$ ordem constitucional brasileira existem vários princípios e garantias constitucionais que servem de parâmetro ao que se entende por "justiça”, como o princípio da moralidade administrativa (Art. 5a , LXXIII), a garantia do acesso à ordem jurídica justa (Art. 5므 XXXV), a garantia do meio ambiente ecologicamente equilibrado, o zelo pela cidadania e pelos direitos do homem, entre outros. 
Dependendo do momento histórico, do tipo de Estado e da opção política, a segurança jurídica é o valor que fala mais alto, mas, se os valores sociais forem os mais valorizados, é a justiça que importa. Assim, embora a segurança jurídica seja um dos pilares do estado democrático de direito, não é um valor absoluto. É da busca pela ponderação entre estes valores que estão surgindo as teses sobre a relativização da coisa julgada.

\section{PRINCÍPIO DA PROPORCIONALIDADE ${ }^{1}$}

O princípio da proporcionalidade surgiu com o novo Estado de Direito, baseado no princípio da "constitucionalidade" e no respeito aos direitos fundamentais. O estado de direito baseado somente no princípio da "legalidade" faliu e o novo estado de direito surgiu fortalecido com a adoção do princípio da proporcionalidade (BONAVIDES, 2003, p. 398-9)2.

Willis Santiago Guerra Filho (2002, p. 83-4) observa que a idéia de proporcionalidade estava presente para os antigos gregos nas noções de comportamento reto, de equilíbrio harmônico e, ainda, na ética aristotélica, na idéia de justiça distributiva. Da mesma forma, também estava presente no antigo Direito Romano e, por fim, conclui que a idéia de proporção praticamente se confunde com a própria idéia do Direito.

A proporcionalidade surgiu no direito moderno como um princípio fundamental de direito de polícia (Direito Administrativo) para depois receber aceitação pelo Direito Constitucional. Atualmente, a proporcionalidade "é algo mais que um critério, regra ou elemento de juízo tecnicamente utilizável para afirmar conseqüências jurídicas, porquanto "é princípio consubstancial ao estado de direito com plena e necessária operatividade’ [...]” (PENALVA, 1990, p. 342).

${ }^{1}$ Vários autores apresentam o princípio da proporcionalidade e o da razoabilidade como se fossem a mesma coisa, mas os constitucionalistas ressaltam que existem diferenças entre os dois princípios, pois o princípio da razoabilidade tem origem norte-americana, como decorrência do due process of law, enquanto o princípio da proporcionalidade tem origem alemã e decorre do princípio da igualdade. E, ainda, segundo Luís Virgílio Afonso da Silva (2002, p. 22-49) tratam-se de princípios que se diferenciam também pela estrutura e pela forma de aplicação. Este trabalho, sem desconsiderar a existência e a importância do princípio da razoabilidade, deter-se-á no estudo do princípio da proporcionalidade e suas especificidades.

${ }^{2}$ Bonavides (2003, p. 399) ressalta que foi por obra da doutrina e jurisprudência da Alemanha e da Suíça que o princípio da proporcionalidade foi convertido em princípio constitucional. 
A doutrina (BONAVIDES, 2003, p. 396-8; GUERRA FILHO, 2002, p. 88; TALAMINI, 2005, p. 566) aponta a existência de três elementos (ou subprincípios) do princípio da proporcionalidade, quais sejam: a adequação; a necessidade ou exigibilidade; e a proporcionalidade em sentido estrito. Nesse sentido, "adequada" é a medida suscetível de atingir o fim escolhido; "necessário" é o meio mais suave para atingir o fim perseguido; e "proporcional em sentido estrito" é a medida que pondera o conjunto de interesses em jogo, trazendo mais vantagens do que desvantagens, no sentido de que o ônus sobre o valor minimizado é menor do que os benefícios do valor prevalecente.

A proporcionalidade é um conceito em evolução e, embora seja reconhecida como um princípio "não escrito" 3 de direito constitucional, pois pertence à natureza e essência mesma do estado de direito, os autores advertem que deve ser aplicada com cuidado, para não acarretar um eventual "estado de juízes" (BONAVIDES, 2003, p. 420) ou "um relaxamento na aplicação da lei” (GUERRA FILHO, 2002, p. 89).

Assim, a maior crítica à adoção indiscriminada do princípio da proporcionalidade é resultado do aumento dos poderes dos juízes e, ainda, a conseqüente diminuição dos poderes do legislador.

Mas Bonavides (2003, p. 426) ressalta que "esse risco se atenua bastante quando entra em conexão com a chamada 'interpretação conforme a Constituição"', configurando um dos métodos mais eficazes de solução de conflitos de princípios.

Guerra Filho (2002, p. 90) conclui que o princípio da proporcionalidade é a mais importante norma-princípio de natureza processual, que conduz a aplicação das demais. Esse autor ressalta que ao contrário das regras, os princípios podem

${ }^{3}$ A proporcionalidade não aparece escrita no texto constitucional, como uma normaprincípio própria, mas Paulo Bonavides (2003, p. 434) explica que ela existe como norma esparsa no texto constitucional e se infere de outros princípios que lhe são afins, como é o princípio da igualdade. $\mathrm{E}$, além de apontar vários dispositivos (exemplo:

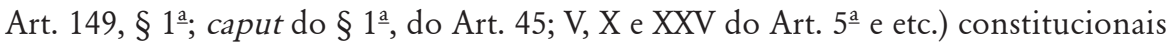
que contém regras ou expressões particularizadas do princípio da proporcionalidade, conclui que esse princípio é direito positivo em nosso ordenamento constitucional, porque está abrangido pelo $\S 2^{\underline{a}}$, do Art. 5a , da CF. O mesmo autor informa que a Convenção e a Corte Européia dos Direitos do Homem elevaram o princípio da proporcionalidade a categoria de princípio geral do direito. E, ainda, segundo Willis Santiago Guerra Filho a Constituição alemã ocidental consagra em seu Art. 19, $2^{\circ}$ parte, o princípio segundo o qual os direitos fundamentais jamais devem ser ofendidos em sua essência, ou seja, permite-se que sejam ofendidos "até um certo ponto", de onde, a contrário sensu, se infere a consagração do princípio da proporcionalidade, para estabelecer o limite que não se deve ultrapassar. 
contradizer-se, sem que percam a validade jurídica, daí ser importante uma "ponderação" na solução dos conflitos entre princípios, a saber:

É exatamente numa situação em que há conflito entre princípios, ou entre eles e regras, que o princípio da proporcionalidade (em sentido estrito ou próprio) mostra sua grande significação, visto que pode ser usado como critério para solucionar da melhor forma tal conflito, otimizando à medida que se acata prioritariamente um e se desatende o mínimo possível o outro princípio. Esse papel cai-lhe muito bem pela circunstância de se tratar de um princípio extremamente formal e, à diferença dos demais, não haver outro que seja seu oposto, que vigore em um ordenamento jurídico digno desse nome. (GUERRA FILHO, 2002, p. 92).

Os princípios não disciplinam nenhuma situação jurídica específica, ao contrário das regras, de forma que os princípios não entram em choque diretamente, são "compatíveis" entre si e, somente em caso de "tensão conflitiva ou quando estão em rota de colisão", cabe a aplicação do princípio da proporcionalidade, para decidir por um princípio em detrimento do outro, naquele caso concreto ${ }^{4}$.

É importante observar que a colisão de princípios ou de direitos fundamentais ocorre "no caso concreto", e, depois de solucionado o conflito, o princípio que restou afastado (ou diminuído) naquele caso, ainda, continua valendo no ordenamento jurídico, razão pela qual pode ser o princípio a prevalecer em outro caso concreto.

No estudo da coisa julgada, a colisão de princípios pode ocorrer quando a segurança jurídica entra em choque com outros valores igualmente constitucionais. Nesse caso, o exemplo que se destaca é o da coisa julgada inconstitucional, uma vez que a coisa julgada em si representa a segurança jurídica e a inconstitucionalidade representa a violação de normas ou princípios constitucionais. Contudo, a grande dúvida é: deve-se preservar "a coisa julgada inconstitucional” ou, ao contrário, deve-se admitir a sua quebra, desconstituição em qualquer caso e em qualquer momento?

Eduardo Talamini (2005, p. 562), com muita propriedade, conclui que se fosse para se estabelecer uma fórmula, ela seria para "a preservação da 'coisa

${ }^{4}$ Guerra Filho (2002, p. 93-94), mais de uma vez destaca que, em caso de conflito de princípios, quando se acata um em detrimento do outro, todos eles se mantêm íntegros em sua validade e apenas diminuídos, circunstancial e pontualmente, em sua eficácia. Esse autor considera o princípio da proporcionalidade como o "princípio dos princípios”, no sentido de que visa solucionar questões aporéticas. 
julgada inconstitucional' e a sua invalidação seria a exceção, a ser concretamente verificada pela aplicação do princípio da proporcionalidade”. Assim, o problema da ponderação de valores deve ser analisado em cada caso concreto, pois o conflito entre princípios pode se manifestar de um jeito em um caso e diferente em outro.

Alguns autores (ASSIS, 2004, p. 31-57; PORTO, 2003, p. 23-32; NERY JÚNIOR, 2004, p. 187-210) defendem que todo problema de ponderação entre valores (segurança jurídica e justiça) deve ser feito somente pelo legislador, como é o caso da ação rescisória, que inegavelmente resulta de uma "ponderação de valores".

Contudo, como a lei não consegue prever todas as situações e eventuais conflitos que possam surgir, deve-se deixar uma margem ou uma pequena abertura para que possa ser preenchida pelo juiz. Nesse caso, caberá ao juiz aplicar o princípio da proporcionalidade no caso concreto para que a solução se aproxime o máximo possível dos ditames da Constituição.

Quando a aplicação do princípio da proporcionalidade, no caso concreto, levar a preponderância de outro valor em face da segurança jurídica, a coisa julgada deve ter sua incidência afastada. Ou seja, o princípio da segurança jurídica cederá parcialmente espaço, será "relativizado" em prol de outro princípio mais relevante no caso concreto. É nessa situação que se propõe a quebra, desconsideração ou relativização da coisa julgada, que somente pode ocorrer em casos especiais e excepcionais, respaldados por critérios de ponderação de valores (princípio da proporcionalidade).

Cândido Rangel Dinamarco (2001, p. 31-78) propõe uma “interpretação sistemática e evolutiva dos princípios e garantias constitucionais do processo civil, ressaltando que nenhum princípio constitui um objetivo em si mesmo", ao contrário, todos eles devem servir para o alcance da efetivação da promessa constitucional de "acesso à justiça" ou acesso à ordem jurídica justa.

Assinale ainda que Dinamarco (2001, p. 31-78) apresenta critérios baseados na teoria das impossibilidades jurídicas e "na ponderação de valores" (princípio da proporcionalidade) para os casos extremos em que seja necessário relativizar (ou desconsiderar) a coisa julgada, pois para esse doutrinador "é absurdo eternizar injustiças para evitar a eternização de incertezas".

Eduardo Talamini (2005, p. 578-613), por sua vez, aponta vários exemplos em que a proporcionalidade é aplicada aos problemas resultantes da intangibilidade da coisa julgada, indicando que existe um caminho ("critérios", para Dinamarco) a ser percorrido para se saber se a coisa julgada deve ser mantida ou não no caso concreto. Assim, segundo o autor, primeiro é preciso observar a “evidência máxima da possibilidade de se obter melhor solução”; depois, é preciso 
"identificar os valores fundamentais envolvidos", pois não é qualquer erro ou injustiça que leva à quebra da coisa julgada; deve-se constatar "o peso concreto dos valores jurídicos envolvidos; e, por último, considerar a relevância da boafe'" 5 .

$\mathrm{Na}$ primeira diretriz indicada pelo autor, tem-se o "erro material" como o defeito mais evidente e suscetível de pronta verificação. Exemplo seria a sentença que reconheceu a paternidade em desconformidade com o resultado do exame de DNA, pois esta decisão estaria incidindo em um erro objetivo, cientificamente comprovado. Contudo, Talamini adverte que somente isso não basta para a "quebra da coisa julgada, o aspecto ora examinado é apenas uma das etapas dos testes a que se submete o caso". Assim, é possível que mesmo no caso do resultado do exame de DNA colidir com a sentença será melhor manter a decisão e respeitar a coisa julgada, em razão dos valores envolvidos ${ }^{6}$.

Nesse exemplo da paternidade ficar reconhecida em exame de DNA, ao contrário do que restou julgado, Luiz Edson Fachin (2002, p. 172) e Luiz Guilherme Marinoni (2004, p. 159-86) ressaltam a importância de se manter a decisão transitada em julgada, quando a filiação afetiva preponderar sobre a filiação biológica.

Portanto, tudo depende da ponderação de valores no caso concreto, não se admitindo que a "dignidade humana", invocada através do direito que a pessoa tem de conhecer sua verdadeira origem (filiação biológica) e, ainda, através do direito a alimentos, sirva, em todos os casos, para desconsiderar a coisa julgada nas sentenças sobre filiação. Nesse sentido, Talamini (2005, p. 591) ressalta que "quando de antemão já se estabelece qual é o resultado da suposta 'ponderação de valores' pretendida, não se está, a rigor, preconizando a aplicação de juízo de ponderação 'nenhum'”.

Ou seja, se em todos os casos a alegação de que foi ferida a dignidade humana é suficiente para desconsiderar a coisa julgada, não existe ponderação de valores,

${ }^{5}$ Em resumo, Talamini (2005, p. 578-602) aplica os três subprincípios da proporcionalidade: adequação; necessidade; e, proporcionalidade em sentido estrito.

${ }^{6}$ No caso da sentença que colide com o resultado do exame de DNA, Eduardo Talamini (2005, p. 582) ressalta que é desaconselhável a quebra da coisa julgada quando já existe uma "relação afetiva" consolidada entre o suposto pai e o suposto filho, pois os tribunais brasileiros têm considerado a necessidade de proteger "situações familiares reconhecidas e consolidadas", como ocorreu nos seguintes julgados: $3^{\circ}$ Turma, REsp 215.249, v.u., rel. Min. C. Alberto Direito, j. 03.10.2002, DJU 02.12.2002 e TJRS, 7oㅡ. Civ., Apel. Civ. 70005276902, rel. Des. Maria Berenice Dias, j. 04.12.2002, RJ 306/117. 
pois o resultado já é certo e presumido. O resultado do conflito de valores no caso concreto, individualizado, é que determinará se a coisa julgada deve ser relativizada ou não. Não existem soluções prontas!

O juiz, no caso concreto, guiado pelo princípio da proporcionalidade, pode verificar que desfazer ou desconstituir a coisa julgada não compensa, sendo menos prejudicial deferir uma providência compensatória ou ressarcitória.

Por último, quanto à aplicação do princípio da proporcionalidade ao instituto da coisa julgada (e sua possível relativização), vale concluir que todo pedido de desconsideração da coisa julgada deve ser analisado com rigor, exigindo-se que a parte autora comprove, de plano, o conflito de valores e o dano que isso causou, causa ou pode causar, pois o ordenamento não admite a litigância temerária.

A coisa julgada somente pode ser desconsiderada (mitigada, relativizada) fora das hipóteses legais em casos realmente especiais e excepcionais, que ressaltam a importância deste instituto para o ordenamento jurídico brasileiro e, em última análise, para o estado democrático de direito.

\section{AS PRINCIPAIS TESES DOUTRINÁRIAS SOBRE A RELATIVIZAÇÃO}

A coisa julgada está presente na redação do inciso XXXVI ("a lei não prejudicará o direito adquirido, o ato jurídico perfeito e a coisa julgada”), do Art. 5aㅡ, da Constituição Federal de 1988. Esse enfoque constitucional impõe limites não só ao legislador, como também ao aplicador da lei, que não pode desrespeitar a coisa julgada, conforme entendimento da jurisprudência ${ }^{7}$ e da doutrina (MARQUES, 1978, p. 236; ARMELIN, 2003, p. 48).

Contudo, a coisa julgada não pode alterar a realidade e a verdade, como fazia no passado, pois não estabelece presunção ou ficção de verdade dos fatos afirmados na sentença, ao contrário, apenas de forma objetiva, prática, torna imutável o resultado da atuação jurisdicional.

A expressão 'relativização da coisa julgada' pode designar uma proposta de revisão legislativa das balizas da coisa julgada; ou uma proposta de flexibilização das hipóteses de cabimento da ação rescisória; ou a desconstituição propriamente dita da coisa julgada, independentemente da ação rescisória.

Ao presente estudo importa os casos de sentenças 'existentes' transitadas materialmente em julgado, com algum vício, injustiça, ilegalidade ou inconstitucionalidade, que não são passíveis de rescisória, ou porque não se

${ }^{7}$ Existem alguns julgados do STF que consolidam este entendimento (RE 92.823, RTJ 99/794; RE 112.405, RTJ 121/373). 
inserem nas hipóteses legais ou porque o prazo de dois anos já transcorreu. Ou seja, não se encaixa neste estudo os casos de sentenças inexistentes, pois estas não fazem coisa julgada e, se não há coisa julgada, não há o que se relativizar.

Entre aqueles processualistas que admitem a relativização da coisa julgada, depois de ultrapassado o prazo da ação rescisória, estão exemplificativamente Cândido Rangel Dinamarco (2001, p. 31-78), Donaldo Armelin (2003, p. 4479), José Augusto Delgado (2005, p. 30-70), Paulo Otero (1993), Humberto Theodoro Júnior (2005, p. 72-125), Juliana Cordeiro de Faria (2005: 72-125), Carlos Valder Nascimento (2005, p. 1-29), Teresa Arruda Alvim Wambier (2003), José Miguel Medina (2003), Alexandre Freitas Câmara (2004, p. 3-29) e Eduardo Talamini (2005), entre outros.

Entre os juristas que não admitem a relativização da coisa julgada estão Leonardo Greco (2004, p. 145-158), Araken de Assis (2004, p. 31-63), Nelson Nery Júnior (2004, p. 187-212), Ovídio Batista da Silva (2004, p. 213-28), Luiz Guilherme Marinoni (2004, p. 159-85), José Carlos Barbosa Moreira (2005, p. 528), entre outros.

Os doutrinadores que são a favor da relativização têm apresentado fortes argumentos, como é o caso de Cândido Rangel Dinamarco (2001, p. 31-78) que, além de considerar a coisa julgada como uma garantia constitucional, entende que ela não é absoluta e deve conviver harmoniosamente com outros valores constitucionais de primeira grandeza.

A teoria das impossibilidades jurídicas, de autoria de Pontes de Miranda (1964), inspirou Dinamarco a concluir que a sentença que transita em julgado, ofendendo a Constituição ou a princípios constitucionais (como a moralidade administrativa, a justa indenização, o meio ambiente ecologicamente equilibrado e outros), na verdade, não faz coisa julgada material, pois contém preceito juridicamente impossível.

Para Dinamarco (2001), existindo decisões absurdas e inconstitucionais, o Juiz deve corrigi-las e saber que, se errar, haverá tribunais capazes de corrigir-lhe o erro. Contudo, ressalta que a regra continua sendo a da intangibilidade da coisa julgada e a relativização é a sua exceção e não o contrário ${ }^{8}$.

A posição defendida por Dinamarco, embora tenha base sólida, é criticada

${ }^{8}$ Dinamarco (2001) ressalta que a sua proposta é apenas oferecer um trato extraordinário a situações igualmente extraordinárias, "com o objetivo de afastar absurdos, injustiças flagrantes, fraudes e infrações à Constituição - com a consciência de que providências destinadas a esse objetivo devem ser tão excepcionais quanto é a ocorrência desses graves inconvenientes”. (p. 70). 
por conceder muito poder ao juiz, que poderá invalidar a decisão de outro juiz, a partir da idéia de que a sentença anterior é injusta ou inconstitucional.

José Augusto Delgado (2005, p. 30-71), por sua vez, utiliza-se de vários exemplos de sentenças injustas ou inconstitucionais para demonstrar, a partir da ponderação de valores, que elas nunca terão força de coisa julgada. Trata a relativização da coisa julgada considerando os princípios constitucionais.

Delgado (2005, p. 52-54) considera injusta, ilegal ou inconstitucional a sentença prolatada:

sem que o demandado tenha sido citado com as garantias exigida pela lei processual; a que autorize a prática de tortura; a que não permita a liberdade na atividade intelectual, artística, científica e de comunicação; a que ofenda, nas relações jurídicas de direito administrativo, o princípio da legalidade, da moralidade, da eficiência, da impessoalidade e da publicidade; a que, no trato de indenização de propriedade pelo poder público, para qualquer fim, não atenda ao princípio da justa indenização; além de vários outros exemplos.

Delgado (2005, p. 64) admite a relativização da coisa julgada em várias hipóteses (inclusive, é criticado pelo casuísmo), mas conclui que "a segurança jurídica imposta pela coisa julgada está vinculada aos princípios da razoabilidade e da proporcionalidade que devem seguir todo ato judicial”.

Teresa Arruda Alvim Wambier e José Miguel Garcia Medina (2003, p. 13) admitem a relativização da coisa julgada, pois o ordenamento não pode permitir “a estabilização de situações indesejáveis”. Propõem um alargamento dos casos de sentenças inexistentes e, ainda, uma interpretação mais "flexível” ou extensiva dos incisos do Art. 485, do CPC (hipóteses de cabimento da ação rescisória), de forma que o inciso V ("violação a literal disposição de lei”) refere-se não apenas a violação ao texto da "lei", mas também engloba decisões que "violem princípios”, pois esta violação é muito mais nociva e prejudicial ao direito.

Eduardo Talamini (2005, p. 402) também admite a relativização da coisa julgada e reduz as sentenças inexistentes (as quais não fazem coisa julgada) àquelas que realmente não possuem os elementos caracterizadores do ato jurisdicional como sentença ${ }^{9}$. Todas as outras sentenças existem e fazem coisa julgada. Portanto, a sua tese de relativização da coisa julgada centra-se apenas nas sentenças existentes, mas que contém algum vício, injustiça ou nulidade. Estas fazem coisa julgada material e podem ser desconstituídas, através dos meios típicos e dos atípicos, quando violam normas ou princípios constitucionais.

${ }^{1}$ Exemplo de sentença inexistente, para Talamini (2005, p. 401), é a sentença prolatada em processo sem citação ou quando esta é nula, ocorrendo a revelia. 
Eduardo Talamini (2005, p. 403), ao admitir a relativização da coisa julgada, prega a ponderação de valores constitucionais, a ser aferida no caso concreto, com a aplicação do "princípio da proporcionalidade, como o único caminho para o legítimo exame da questão"10.

Os juristas que negam a relativização da coisa julgada apresentam diferentes argumentos. Assim, Leonardo Greco (2004, p. 145-57) considera que a coisa julgada é uma garantia constitucional decorrente da segurança jurídica e, como tal, não pode ser relativizada.

Nelson Nery Junior destaca a importância da coisa julgada como "elemento essencial do Estado Democrático de Direito" e, ainda, ressalta que a coisa julgada material é um "substitutivo" de todas as atividades das partes e do juiz, de modo que a sentença transitada em julgado abarca todas as nulidades ocorridas durante o processo (2004, p. 187-211) $)^{11}$.

Esse jurista é contra qualquer tipo de relativização da coisa julgada não prevista pelo ordenamento jurídico, pois argumenta que o sistema constitucional brasileiro optou pelo "justo possível”"12, consubstanciado na segurança jurídica da coisa julgada material.

Nery Junior enfatiza que "passados os dois anos do prazo para o exercício da pretensão rescisória, dá-se o fenômeno da 'coisa soberanamente julgada', não mais modificável, qualquer que seja o motivo alegado pelo interessado" (NERY JUNIOR, 2004, p. 198-9 $)^{13}$. Assim, para esse autor somente com a modificação da lei, nela incluindo a hipótese de exceção, é que poderão ser abrandados os rigores da coisa julgada, pois, sem expressa disposição de lei, não poderá ser desconsiderada a coisa julgada (NERY JUNIOR, 2004, p. 200) ${ }^{14}$.

${ }^{10}$ A tese de Talamini está presente em grande parte deste trabalho, que a acata pela coerência de argumentos.

${ }^{11}$ Nery Jr. destaca o efeito especial da coisa julgada material como "substitutivo", decorrente da função substitutiva da jurisdição.

${ }^{12}$ Existe o justo absoluto, mas este é utópico, por isto, faz-se uma opção política pelo justo possível, que é realizável.

${ }^{13}$ Mesmo as sentenças ilegais ou inconstitucionais não podem ser desconstituídas (ou relativizadas), depois do prazo de dois anos da ação rescisória, no entendimento de Nery Junior.

${ }^{14}$ No caso de ação de investigação de paternidade, com coisa julgada anterior de improcedência por insuficiência de provas (não existia o exame de DNA, por exemplo), Nelson Nery Junior (2004, p. 206-11) propõe que precisaria ser editada uma lei para autorizar a ocorrência da coisa julgada secundem eventum probationis, para ambos os litigantes - pai e filho. 
No caso de ação de investigação de paternidade julgada improcedente por insuficiência ou falta de provas, Nery Junior $(2004 \text {, p. 205 })^{15}$ considera que seria possível a repropositura da ação, com base nas novas técnicas de perícia genética (DNA), pois estar-se-ia diante de uma "nova causa de pedir".

Luiz Guilherme Marinoni (2004, p. 159-86), ao escrever sobre o princípio da segurança dos atos jurisdicionais, relacionado à relativização da coisa julgada material, destaca que o problema do conflito entre justiça e segurança atinge a filosofia do direito e coloca-se como "uma das principais questões jurídicas ainda sem solução ideal”.

Para Marinoni (2004, p. 162) "a coisa julgada é atributo indispensável ao Estado Democrático de Direito e à efetividade do direito fundamental de acesso ao Poder Judiciário”, razão pela qual não admite qualquer relativização da coisa julgada depois de ultrapassado o prazo de dois anos da ação rescisória. O jovem jurista argumenta que se o problema é de justiça, ninguém garante que a segunda decisão que visa relativizar a coisa julgada também não seja injusta e errônea.

Qualquer ponderação de valores somente pode ser feita pelo legislador, como já acontece nas hipóteses da ação rescisória que, segundo Marinoni, devem ser interpretadas restritivamente.

Ovídio Baptista da Silva também é contra a relativização da coisa julgada, pois argumenta que os autores divagam em um terreno abstrato, com conceitos indeterminados ("grave injustiça, sentença abusiva", etc), "pretendendo desmoronar o edifício da coisa julgada” (SILVA, 2004, p. 213-28).

Baptista da Silva (2004, p. 219) entende que a "injustiça da sentença nunca foi e nem poderá ser fundamento para afastar o império da coisa julgada”, e registra que o que mais lhe preocupa é a busca de reforma ad aeternum ${ }^{16}$.

${ }^{15}$ Neste caso, Nery Junior (2004, p. 206) destaca que "esta não é a solução ideal, mas é melhor do que a que 'relativiza' a coisa julgada porque, pelo menos, submete-se ao Estado Democrático de Direito e não pretende impor comportamento nazista ao Poder Judiciário e aos cidadãos brasileiros e residentes no País".

${ }^{16}$ Segundo Ovídio Baptista da Silva (2004, p. 219): "de todos os argumentos concebidos pela doutrina, através dos séculos, para sustentar a necessidade de que os litígios não se eternizem, parece-me que o mais consistente reside, justamente, na eventualidade de que a própria sentença que houver reformado a anterior, sob o pressuposto de conter injustiça, venha a ser mais uma vez questionada como injusta; e assim ad aeternum, sabido, como é, que a justiça, não sendo um valor absoluto, pode variar, não apenas no tempo, mas entre pessoas ligadas a diferentes crenças políticas, morais e religiosas, numa sociedade democrática que se vangloria de ser tolerante e 'pluralista' quanto a valores". 
Esse autor (SILVA, 2004, p. 213) não admite a "relativização" da coisa julgada, mas aceita a idéia de que é preciso alterar o sistema processual referente a coisa julgada para se adequar a tendência da "modernidade líquida" 17 , ainda que isso seja o mesmo que retornar às origens.

Barbosa Moreira (2005, p. 5-28), por sua vez, é categórico em afirmar que "no plano da legislação ordinária em vigor" no Brasil, não é possível qualquer tipo de relativização da coisa julgada material fora dos limites já previstos pelo ordenamento jurídico (recurso extraordinário, ação rescisória no processo civil e revisão criminal no processo penal).

Este autor expõe o problema das conseqüências práticas que podem decorrer da relativização da coisa julgada, sendo que, se um juiz pode considerar injusta ou inconstitucional a sentença transitada em julgado proferida por um colega, o que impedirá o litigante, vencido no segundo julgamento, de impugnar em juízo essa segunda sentença e impugnar indefinidamente? ${ }^{18}$

Responde Barbosa Moreira (2005, p. 25): “o óbice concebível seria a coisa julgada; mas, se ele pôde ser afastado com relação à primeira sentença, por que não poderá sê-lo quanto à segunda”?

Porém, em alguns casos (como é caso da ação de investigação de paternidade transitada em julgado, quando ainda não existia o exame de DNA), Barbosa Moreira aceita que a coisa julgada possa ser desconsiderada, conforme proposta de lege ferenda:

O mais importante, ao menos do ponto de vista prático, é a descoberta científica poder demonstrar a erronia da solução dada anteriormente ao litígio, em época na qual não era possível contar com determinada prova. Para a hipótese do exame de DNA, como registrado, a jurisprudência já vem atenuando, por via interpretativa, o rigor do texto do Código (art. 485, VII), para admitir a rescisória com fundamento no laudo pericial, incluído no conceito de "documento novo". Contudo, nos casos em que já passou o biênio legal, é conveniente modificar aí a disciplina, não para abolir o pressuposto temporal [...], mas para fixar o termo inicial do prazo no dia em que o interessado obtém o laudo, em vez do trânsito em julgado da sentença rescindenda. (MOREIRA, 2005, p. 28).

${ }^{17}$ Este termo é utilizado por Zygmunt Bauman, citado por Ovídio Baptista da Silva (2004, p. 213), como contraposição à "primeira modernidade". Na "modernidade líquida" tudo é um desfazer (demancha-se com facilidade), não existindo nada de permanente.

${ }^{18}$ Conforme se infere deste trabalho, esta também é a preocupação de Luiz Guilherme Marinoni e Ovídio Baptista da Silva. 
Ainda, o eminente jurista acrescenta à sua proposta de lege ferenda, o caso da sentença transitada em julgado que aplica lei já declarada inconstitucional pelo STF, pois, nesse caso, ele admite que seria cabível a ação rescisória "a qualquer tempo”, com base no Art. 485, V, do CPC, porque a sentença terá violado a Constituição (MOREIRA, 2005, p. 28).

De todas as teses acima, a favor ou contra a relativização da coisa julgada material, pode-se concluir que não é possível ser tão liberal ao ponto de aceitar que a coisa julgada deva ser relativizada sempre (a relativização seria a regra e a exceção seria a intangibilidade da coisa julgada); mas também não se pode ser tão conservador para se admitir a relativização somente nos casos taxativamente previstos em lei.

Busca-se um ponto de equilíbrio ou de ponderação, pois, enquanto não são feitas alterações legislativas para prever expressamente hipóteses de relativização da coisa julgada em casos extremos, estes casos precisam ser resolvidos pelo ordenamento jurídico-processual brasileiro.

Nem tão formalista (baseado na preservação da coisa julgada como corolário da segurança jurídica) nem tão materialista (a justiça como ideal do processo e das propostas de relativização), o jurista deve analisar o caso concreto para, a partir da ponderação de valores e com base nos critérios oferecidos pelo princípio da proporcionalidade, resolver o conflito, relativizando ou não a coisa julgada conforme a melhor solução para o ordenamento jurídico e para o Estado Democrático de Direito brasileiros.

\section{AÇÃO RESCISÓRIA}

A doutrina aponta muitos remédios para desconstituir a coisa julgada civil, como o habeas corpus; o mandado de segurança; os embargos à execução ${ }^{19}$; a argüição de descumprimento de preceito fundamental; a ação rescisória; e a ação declaratória de nulidade (ou de inexistência) ${ }^{20}$. Além de outros meios próprios, que são apresentados pelos doutrinadores em propostas de lege ferenda.

19 Os embargos do executado, no caso do parágrafo único do Art. 741 do CPC, transformados no $§ 11^{\underline{a}}$ do Art. 475-L pela edição da Lei 11.232 de 22/12/2005, consistem em importante meio de impugnação à decisão judicial transitada em julgado que contenha alguma inconstitucionalidade, ainda, fora do prazo da ação rescisória.

${ }^{20}$ A ação declaratória de inexistência ou querela nullitatis, por sua vez, não é meio de relativizar a coisa julgada material, pois apenas é uma forma de impugnar as sentenças inexistentes e não as sentenças nulas. As sentenças inexistentes, que são aquelas proferidas por um não-juiz, ou sem dispositivo, ou, ainda, sem citação com revelia, não transitam em julgado e, portanto, são passíveis de declaração a qualquer tempo 
Contudo, não é adequado examinar a relativização da coisa julgada utilizandose como instrumento processual a ação declaratória de inexistência, pois esta visa retirar do ordenamento apenas a sentença inexistente, que não faz coisa julgada. As sentenças injustas ou inconstitucionais, que fazem coisa julgada, devem ser desconstituídas através da ação rescisória.

Assim, a ação rescisória é o meio mais adequado para relativizar a coisa julgada material injusta ou inconstitucional.

A ação rescisória, como o próprio nome diz, é uma ação e não um recurso, pois visa desconstituir a decisão acobertada pela coisa julgada material, segundo o Art. 485 do CPC. Trata-se de ação porque é um meio de impugnação de decisão externo ao processo.

Segundo Pontes de Miranda (1964, p. 69), a ação rescisória é "uma ação constitutiva negativa”, que visa desfazer ou desconstituir a decisão acobertada pela coisa julgada através do iudicium rescindens e, ainda, pode pretender a emissão de um novo pronunciamento que substitua o anterior através do iudicium rescissorium ${ }^{21}$.

A ação rescisória é de competência originária do segundo grau de jurisdição, devendo ser intentada nos tribunais de segundo grau, ou até no STF ou no STJ, nos casos em que a competência cabe a esses órgãos superiores (PONTES DE MIRANDA, 1964, p. 69) 22. Ainda, segundo o Art. 495, do CPC, o prazo para a propositura da ação rescisória se extingue em 2 (dois) anos, contados do trânsito em julgado da decisão.

A doutrina brasileira, apoiada na preservação da segurança jurídica, sempre defendeu que o rol das hipóteses de rescisão do Art. 485 do CPC é exaustivo e não exemplificativo, não sendo possível o emprego da analogia para dar causa à rescisória. Mas, com as teses recentes sobre o estudo da relativização da coisa julgada, tem-se cogitado de "flexibilizar" as hipóteses de cabimento da ação rescisória e até, em casos de extrema gravidade, de retirar a limitação temporal.

e de qualquer forma. A ação declaratória de inexistência é uma ação autônoma, de competência funcional do mesmo juízo do processo que lhe deu causa e sem prazo.

${ }^{21} \mathrm{O}$ iudicium rescissorium não se confunde com o iudicium rescindens, segundo destaca Pontes de Miranda (1964, p. 70), pois “uma coisa é o juízo que 'retoma' a prestação jurisdicional, que havia sido entregue; outra, aquele em que à 'relação jurídica processual', se existiu e se valia, ou restabelecida ou estabelecida 'ex novo', corresponda a nova 'prestação jurisdicional”'. A previsão destes juízos de rescisão está no Art. 494 do CPC.

${ }^{22}$ Pontes de Miranda (1964, p. 71) ressalva que a ação rescisória será sempre de competência do juízo "igual ou superior". 
Alexandre Freitas Câmara defende que a ação rescisória é um meio adequado para a rescisão de sentenças acobertadas pela coisa julgada inconstitucional. Esse autor apresenta proposta de lege ferenda, com vistas a acrescentar um novo inciso ao Art. 485 do CPC, no qual restaria estabelecido "que a sentença de mérito transitada em julgado poderia ser rescindida quando ofendesse norma constitucional" (2004, p. 27) e, neste caso, não deveria se submeter ao prazo decadencial de 2 anos.

Barbosa Moreira (2005, p. 28) também enfrentou a questão e admite que, no caso de sentença que "haja aplicado lei já declarada inconstitucional pelo STF", a hipótese se enquadraria no Art. 485, V, do CPC, vez que a sentença terá violado a constituição. Mas no caso de já ter ultrapassado o prazo do biênio legal da rescisória, "em atenção à particular gravidade do vício, seria razoável permitir, a título excepcional, o ajuizamento da rescisória a qualquer tempo".

Parece razoável a interpretação que admite a interposição da ação rescisória no caso de sentença acobertada pela coisa julgada inconstitucional. Mas o problema surge quando já escoou o prazo de dois anos para a rescisão, razão que leva a doutrina a apresentar as propostas de lege ferenda.

Eduardo Talamini (2005, p. 648), depois de estudar exaustivamente o tema, conclui que a relativização da coisa julgada inconstitucional pode ocorrer através de "uma quebra atípica da coisa julgada", de absoluta excepcionalidade e "equivalente a uma ação rescisória extraordinária”. Esse meio "atípico", destaca esse autor, deve se submeter ao mesmo regime de competência e de "rescisão" do processo rescisório "típico”, ou seja, a competência originária será do segundo grau de jurisdição e será possível desfazimento total ou parcial do julgado anterior e nova decisão.

Nem sempre será mais vantajoso desconsiderar (relativizar) a coisa julgada inconstitucional, podendo existir situações consolidadas no caso concreto que determinem ser melhor a preservação da coisa julgada e da segurança jurídica. Somente a ponderação de valores no caso concreto será capaz de determinar se é melhor relativizar ou não a coisa julgada, não existindo soluções préestabelecidas.

Com relação às sentenças proferidas em ações de investigação de paternidade antes do advento do exame de DNA e, depois, com a realização do exame, descobre-se que a filiação biológica existe ou não, ao contrário do que restou julgado, os doutrinadores se debatem sobre qual seria o meio de rescindir essa sentença, uma vez transcorrido o prazo da ação rescisória. Mas, quando ainda não escoou o prazo de dois anos da ação rescisória para desfazer a sentença 
proferida na ação de investigação de paternidade no mesmo caso, também existe a polêmica em qual das hipóteses do Art. 485 do CPC enquadrar-se-ia o exame de DNA.

Alguns autores tentam enquadrar o resultado do exame de DNA no inciso VII do Art. 485, pois ele constituiria um "documento novo" que a parte não pode fazer uso no curso do processo anterior, mas que, por si só, seria o bastante para lhe assegurar pronunciamento favorável. Esse é o entendimento de Barbosa Moreira (2005, p. 22) e, ainda, do Superior Tribunal de Justiça ${ }^{23}$.

Contudo, se o prazo da rescisória já tiver escoado, Barbosa Moreira admite que, nesse caso específico, pode ser feita uma mudança legislativa para alterar a contagem do prazo da ação rescisória (mas ressalta-se: esse autor não abre mão do prazo). Assim, "o termo inicial do prazo seria fixado no dia em que o interessado obtém o laudo, em vez do trânsito em julgado da sentença rescindenda" (MOREIRA, 2005, p. 28) ${ }^{24}$.

Eduardo Talamini (2005, p. 662-3), baseado no ordenamento jurídico alemão, na revisão criminal e no direito canônico, propõe que, nessa situação específica, "relativa ao estado de pessoa", seria melhor uma alteração legislativa para criar uma "nova modalidade de ação rescisória", que não se submeteria ao prazo decadencial e, ainda, poderia basear-se em "novas provas ou argumentos".

Admitir, entretanto, "novos argumentos" como meio de rescindir sentença transitada em julgado, a qualquer tempo, não parece ser o mais adequado, ao contrário, pode até ser perigoso, se não se delimita "o que pode se enquadrar como novos argumentos”.

Assim, no âmbito da ação rescisória o que se percebe é que quase todas as propostas visam ampliar o cabimento dessa ação desconstitutiva, em busca da relativização da coisa julgada, quando esta for necessária.

${ }^{23}$ REsp 300.084, acórdão de 28.04.2004, publicado no DJ 06.09.2004, cuja ementa dispõe: "O laudo do exame de DNA, mesmo posterior ao exercício da ação de investigação de paternidade, considera-se 'documento novo' para aparelhar a ação rescisória (CPC, Art. 485, VII). É que tal exame revela prova já existente, mas desconhecida até então. A prova do parentesco existe no interior da célula. Sua obtenção é que apenas se tornou possível quando a evolução científica concebeu o exame intracitológico".

${ }^{24}$ No mesmo sentido de Barbosa Moreira, caminha Marinoni (2004, p. 179), que advoga que "o prazo da ação rescisória deve decorrer a partir da ciência da parte a respeito da existência dessa técnica" (referindo-se ao exame de DNA). 


\section{CONCLUSÃO}

A relativização da coisa julgada, embora em caráter excepcional, deve ser enfrentada pelos operadores do direito, sendo que a solução depende da ponderação de valores no caso concreto.

As sentenças acobertadas por coisa julgada inconstitucional existem e precisam ser desconstituídas por meio dos instrumentos legais, como a ação rescisória (Art. 485, V, do CPC), os embargos à execução (Art. 741, parágrafo único, do CPC) ou impugnação (depois da entrada em vigor da Lei 11.232/05, que acrescentou o Art. 475-L, § 1 $1^{a}$, ao CPC), ou até por meio de ação desconstitutiva "atípica", que se sujeita ao mesmo regime jurídico da rescisória, menos ao prazo decadencial de dois anos.

A ação declaratória não parece ser a melhor solução, pois é cabível somente contra as sentenças "inexistentes”. E, ainda, como tais sentenças não fazem coisa julgada, não se pode dizer que existe uma "relativização" da coisa julgada, com a declaração de inexistência a qualquer tempo.

Para as sentenças injustas ou inconstitucionais é melhor deixar a possibilidade de relativizar a coisa julgada após a análise do caso concreto, ponderando-se os valores envolvidos por meio de uma ação de desconstituição, com as características da ação rescisória, mas sem prazo, ou ainda, sem prazo tão exíguo.

Assim, seria viável uma alteração legislativa para acrescentar mais uma hipótese de cabimento da ação rescisória contra sentença "inconstitucional” não sujeita a prazo. Até porque já existe a previsão de impugnar tal sentença através dos embargos à execução ou de impugnação (CPC, Art. 741, parágrafo único e Art. 475-L, $\left.\S 1^{\underline{a}}\right)$.

Para os casos de sentenças “injustas”, que transitam materialmente em julgado, a doutrina e a jurisprudência devem aplicar o princípio da proporcionalidade, no caso concreto, para ora afastar a segurança jurídica em prol da justiça, ora afastar esta em prol daquela, uma vez que nenhum desses valores é absoluto no estado democrático de direito.

\section{REFERÊNCIAS}

ALVIM WAMBIER, Teresa Arruda; GARCÍA MEDINA, José Miguel. O dogma da coisa julgada: hipóteses de relativização. São Paulo: Editora Revista dos Tribunais, 2003.

ARMELIN, Donaldo. Flexibilização da coisa julgada. Revista da Procuradoria Geral do Estado de São Paulo, São Paulo, ed. especial, p. 41-88, jan./dez. 2003. (Edição Especial: 30 anos do Código de Processo Civil). 
ASSIS, Araken de. Eficácia da coisa julgada inconstitucional. In: DIDIER JR., Fredie (Coord.). Relativização da coisa julgada: enfoque crítico. Salvador: JusPODIVM, 2004. (Coleção de Temas de Processo Civil: Estudos em Homenagem a Eduardo Espínola; v. 2.).

BONAVIDES, Paulo. Curso de Direito Constitucional. 13. ed. rev. e atual. São Paulo: Malheiros, 2003.

CÂMARA, Alexandre Freitas. Relativização da Coisa Julgada Material. In: DIDIER JR, Fredie (Coord.). Relativização da coisa julgada: enfoque crítico. Salvador: JusPODIVM, 2004. (Coleção de Temas de Processo Civil: Estudos em Homenagem a Eduardo Espínola; v. 2).

COUTURE, Eduardo J. Fundamentos do Direito Processual Civil. São Paulo: Saraiva, 1946.

DELGADO, José Augusto. Efeitos da coisa julgada e os princípios constitucionais. In: NASCIMENTO, Carlos Valder do. (Coord.). Coisa Julgada Inconstitucional. 5. ed. Rio de Janeiro: América Jurídica, 2005, p. 30-71.

DINAMARCO, Cândido R. Instituições de Direito Processual Civil. 4. ed. rev. e atual. São Paulo: Malheiros, 2004. 4v.

- Relativizar a coisa julgada material. Revista da Procuradoria-Geral do Estado de São Paulo. São Paulo, n. 55/56, p. 31-77, jan./dez. 2001.

FACHIN, Luiz Edson. Paternidade e ascendência genética. In: LEITE, Eduardo de Oliveira (Coord.). Grandes temas da atualidade - DNA como meio de prova da filiação: aspectos constitucionais, civis e penais. 2. ed. Rio de Janeiro: Forense, 2002.

GRECO, Leonardo. Eficácia da declaração erga omnes de constitucionalidade ou inconstitucionalidade em relação à coisa julgada anterior. In: DIDIER JR, Fredie (Coord.). Relativização da coisa julgada: Enfoque crítico. Salvador: JusPODIVM, 2004. (Coleção de Temas de Processo Civil: Estudos em Homenagem a Eduardo Espínola; v. 2).

GUERRA FILHO, Willis Santiago. A Filosofia do direito: aplicada ao direito processual e à teoria da constituição. 2 ed. São Paulo: Atlas, 2002.

LIEBMAN, Enrico Tullio. Eficácia e autoridade da sentença e outros escritos sobre a coisa julgada. Trad. A. Buzaid e B. Aires, notas A. P. Grinover. 3 ed. Rio de Janeiro: Forense, 1984. 
MARINONI, Luiz Guilherme. O princípio da segurança dos atos jurisdicionais (a questão da relativização da coisa julgada material). In: DIDIER JR, Fredie (Coord.). Relativização da coisa julgada: enfoque crítico. Salvador: JusPODIVM, 2004. (Coleção de Temas de Processo Civil: Estudos em Homenagem a Eduardo Espínola; v. 2).

MARQUES, José Frederico. Manual de direito processual civil. 6. ed. rev., atual. e adaptada a Emenda Constitucional n. 7. São Paulo: Saraiva, 1978. 2v.

MOREIRA, José Carlos Barbosa. Temas de Direito Processual. Quinta Série. São Paulo: Saraiva, 1984.

. Considerações sobre a chamada "relativização" da coisa julgada material. Revista Síntese de Direito Civil e Processual Civil, Porto Alegre, v. 6, n. 33, p. 528, jan./fev., 2005.

NASCIMENTO, Carlos Valder do (Coord.). Coisa Julgada Inconstitucional. Coisa Julgada Inconstitucional. 5 ed. Rio de Janeiro: América Jurídica, 2005.

NERY JUNIOR, Nelson. A Polêmica sobre a relativização (desconsideração) da coisa julgada e o Estado Democrático de Direito. In: DIDIER JR, Fredie (Coord.). Relativização da coisa julgada: enfoque crítico. Salvador: JusPODIVM, 2004. (Coleção de Temas de Processo Civil: Estudos em Homenagem a Eduardo Espínola; v. 2).

OTERO, P. Ensaio sobre o caso julgado inconstitucional. Lisboa: Lex, 1993.

PENALVA, Ernesto Pedraz. Constituición, Jurisdicción y Proceso. Madri: Akal, 1990.

PONTES DE MIRANDA. Tratado da ação rescisória das sentenças e de outras decisões, Rio de Janeiro: Forense, 1964.

PORTO, Sérgio Gilberto. Cidadania processual e relativização da coisa julgada. Revista de Processo, São Paulo, ano 28, n. 112, p. 23-32, out./dez. 2003.

SILVA, Ovídio A. Baptista da. Coisa Julgada relativa? In: DIDIER JR, Fredie (Coord.). Relativização da coisa julgada: enfoque crítico. Salvador: JusPODIVM, 2004. (Coleção de Temas de Processo Civil: Estudos em Homenagem a Eduardo Espínola; v. 2).

SILVA, Luís Virgílio Afonso da. O proporcional e o razoável. Revista dos Tribunais, ano 91, v. 798, p. 22-49, abr. 2002.

TALAMINI, Eduardo. Coisa julgada e sua revisão. São Paulo: Editora Revista dos Tribunais, 2005. 
THEODORO JÚNIOR, Humberto; FARIA, Juliana Cordeiro de. A Coisa Julgada Inconstitucional e os Instrumentos Processuais para seu Controle. In: NASCIMENTO, Carlos Valder do. (Coord.). Coisa julgada inconstitucional. 5. ed. Rio de Janeiro: América Jurídica, 2005. 